\title{
Herbesin oor die opleiding van natuurwetenskaponderwysers in Suid-Afrika: Lesse uit Finland
}

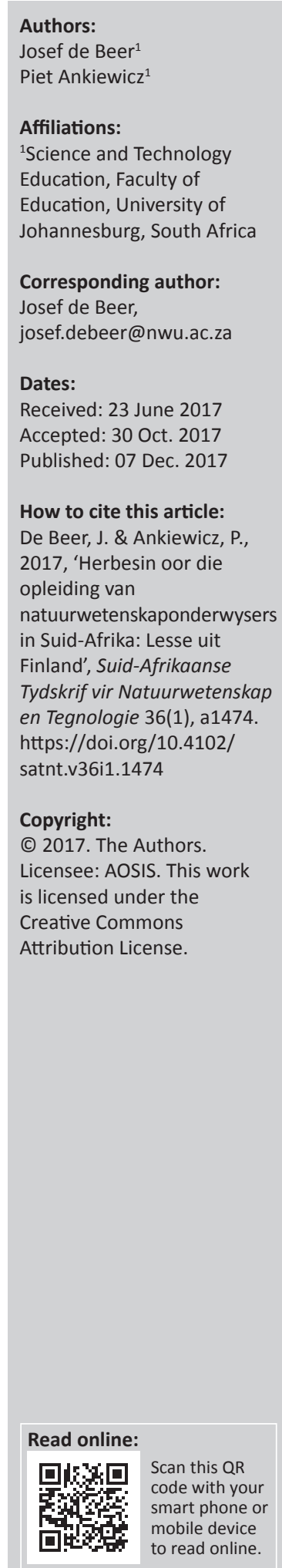

Finland word dikwels gesien as die 'goudstandaard' in natuurwetenskaponderwys, danksy die land se uitmuntende prestasie in internasionale toetse soos die program vir internasionale studentassessering (PISA) en tendense in internasionale wiskunde- en natuurwetenskapstudie (TIMSS). Daarteenoor laat Suid-Afrika se prestasie in TIMSS veel te wense oor. Volgens die Wêreld-Ekonomiese Forum (WEF) se wêreldwye mededingendheidsverslag (2010-2011), is Suid-Afrika 137ste op die ranglys van 139 lande wat betref die gehalte van wiskundeen natuurwetenskaponderwys. Die skrywers van hierdie artikel beskou die gehalte van natuurwetenskaponderwysers as die sleutel om hierdie probleem die hoof te bied. Ons dink na oor Finland as die 'superoutoriteit' in natuurwetenskaponderwys en oor lesse wat SuidAfrika kan leer omtrent die verskaffing van beter voordiensopleiding vir studente wat hulle as natuurwetenskaponderwysers wil bekwaam. In hierdie artikel verbind ons ontluikende temas wat uit kwalitatiewe navorsingsdata na vore gekom het met aanbevelings oor hoe voordiensopleiding vir voornemende onderwysers verbeter kan word, gebaseer op die beste gebruike in Finland. Ons gebruik onderhoude met Finse onderwysers en onderwysdosente, skoolwaarneming in beide lande, artefakte soos die refleksies van Suid-Afrikaanse onderwysstudente oor hulle ondervindings in skole, en onderwysers se reaksies op die Sienings van die Aard van Natuurwetenskappe (Views of the Nature of Science)-vraelys. Die derdegenerasie-kultuurhistoriese aktiwiteitsteorie (KHAT) word gebruik as 'n navorsingslens om 'spanning/onderstrominge' in natuurwetenskaponderwys in Suid-Afrika te beklemtoon, en ons dui aan hoe hierdie aspekte by die opleiding van onderwysers verreken kan word.

Reimagining science teacher education in South Africa: Lessons from Finland. Finland is often seen as the 'gold standard' in science education, due to its excellent performance in international tests like PISA and TIMSS. South Africa's performance in TIMSS, on the other hand, leaves much to be desired. According to the Global Competitiveness Report (2010-2011), South Africa ranked 137th out of 139 countries in quality of mathematics and science education. The authors of this paper see the quality of science teachers as the key to addressing this concern. We reflect on Finland as the 'superpower' in science education and on lessons South Africa may learn in terms of providing better preservice teacher education to future science teachers. In this article emerging themes from qualitative research data are linked to recommendations on how preservice teacher education may be improved, based on best practices in Finland. We draw on interviews with Finnish teachers and teacher educators; school observations in both countries; artefacts such as the reflections of South African student teachers on their school experience; and teachers' responses on the Views of the Nature of Science questionnaire. Third-generation CulturalHistorical Activity Theory (CHAT) is used as a research lens to highlight 'tensions' experienced in science education in South Africa and we indicate how these aspects may be addressed in teacher education.

\section{Inleiding Natuurwetenskaponderwys in Suid-Afrikaanse skole: Kan die feniks weer uit die as opstaan?}

Suid-Afrika benodig innoverende, kreatiewe natuurwetenskaplikes om mededingend te wees in die wêreldekonomie, en die sleutel om dit te vermag, is die drastiese verbetering van natuurwetenskaponderwys in skole (Sentrum vir Ontwikkeling en Onderneming 2011). 'n Primêre beperking ten opsigte van die lewering van natuurwetenskaponderwys van hoë gehalte is bes 
moontlik die tekort aan effektiewe voordiensopleiding van onderwysers, asook onvoldoende professionele ontwikkeling van diensdoende onderwysers.

Dit ontbreek Suid-Afrikaanse natuurwetenskaponderwysers dikwels aan die nodige pedagogiese inhoudskennis (PIK) om natuurwetenskap effektief te kan onderrig en die verwagte oop ondersoek, soos vervat in die nasionale kurrikulum in Suid-Afrika (die Kurrikulum-en Assesseringsbeleidsverklaring [KABV]), word dan vervang deur transmissiemodus-onderwys (De Beer \& Ramnarain 2012). Onlangse navorsing het getoon dat leerders in Suid-Afrika slegs beperkte geleenthede in die natuurwetenskapklaskamer kry om deur ondersoek te leer (Ramnarain 2007; Rogan \& Aldous 2005). Leerders word feite geleer, maar ontwikkel nie die nodige vaardighede om te ontdek hoe die fisiese en natuurlike wêreld werk nie. Daarbenewens, wanneer ondersoekgebaseerde onderrig wel plaasvind, is dit hoofsaaklik onder die beheer van die onderwyser, en leerders is net betrokke by die analise van data wat ingesamel is en om tot gevolgtrekkings te kom. Indien praktiese werk gedoen word, word 'n 'resepteboek'-benadering dikwels gebruik, wat leerders nie by hipotesetoetsing betrokke kry of aanmoedig om oor die aard van natuurwetenskap (AVW) na te dink nie (De Beer \& Ramnarain 2012). Hailman (1975) was vier dekades gelede van mening dat benadering tot die 'natuurwetenskaplike metode' in skole dikwels so ver verwyderd is van hoe 'n Einstein sou gewerk het as wat 'inkleur volgens nommers' is van die skildertegnieke van Michelangelo. Hierdie metafoor is tot groot mate van toepassing op die Suid-Afrikaanse natuurwetenskapklaskamer, wat dikwels gekenmerk word deur 'n onderwysergesentreerde onderrigmetodiek van die mentor-onderwysers, wat die professionele ontwikkeling van onderwysstudente tydens werkgeïntegreerde leer (WIL) behoort te steierbou.

\section{Natuurwetenskaponderwys in Finland: Die klaskamer as 'n epistemologiese ruimte vir die ontwikkeling van môre se natuurwetenskaplikes}

Die Suid-Afrikaanse ondervinding wat hierbo beskryf is, is in skerp teenstelling met Finland wat natuurwetenskaponderwys suksesvol herskep het en wat waardevolle lesse aan SuidAfrika bied. Ons data toon 'n leerkultuur in Finse skole. Leerders trek wit laboratoriumjasse aan wanneer hulle in natuurwetenskapklaskamers instap. Deur hierdie eenvoudige handeling betree hulle ' $n$ ander epistemologiese ruimte, naamlik die wêreld van die natuurwetenskap. Deur middel van goed gestruktureerde, ondersoekende leeraktiwiteite begelei die onderwyser die leerders op 'n kundige wyse tydens hulle ondersoekende reis.

Onderwysopleidingsprogramme in Suid-Afrika behoort krities ondersoek te word om vas te stel of onderwysers voldoende voorberei is om onderrig te gee vanuit grondige begrip van die aard van die natuurwetenskap. Finland het tydens die 1980's 'n gewone opleidingstelsel gehad (Sahlberg 2010), en het nietemin tydens enkele dekades na die voorpunt in die wêreld gevorder. Ons voer aan dat deur oor die voordiensopleiding van natuurwetenskaponderwysers te herbesin en deur uit die suksesvolle transformasiepraktyke in lande soos Finland te leer, verbetering in natuurwetenskaponderwys ' $n$ werklikheid in Suid-Afrika kan word.

\section{Navorsingsmetodologie}

Die doel van hierdie navorsing was om die kultuurhistoriese aktiwiteitsteorie (KHAT) op 'n onkonvensionele manier te gebruik om die Finse en Suid-Afrikaanse natuurwetenskaponderwysstelsels te vergelyk. Die vraag waardeur die navorsing gerig is, was: Watter beste gebruike in Finland (ook ten opsigte van voordiensopleiding van onderwysers) hou belofte in vir die verbetering van natuurwetenskaponderwys in Suid-Afrika? Hierdie artikel doen verslag oor kwalitatiewe navorsing en is geskryf as 'n konseptuele artikel om die temas wat uit die data vorendag gekom het, te verbind met hoe die skoolondervinding van voordiens-onderwysopleiding in Suid-Afrika verbeter kan word op grond van die beste gebruike in Finland.

\section{Insameling en analise van data}

Ons het individuele onderhoude gevoer met twee gesoute Finse natuurwetenskaponderwysers en een Finse onderwysdosent in Helsinki. Die onderhoude is getranskribeer en gekodeer, en temas is uit die data gedistilleer. Ons het inligting verkry deur skoolbesoeke in Finland (ons het vier lesse in September 2014 in Helsinki bygewoon), asook in Suid-Afrika (waar die twee skrywers talle lesse van onderwysers en studente-onderwysers oor twee dekades bygewoon het). Ons het die Hervormde Onderrigwaarnemingsprotokol (Reformed Teaching Observation Protocol [RTOP]) instrument hiervoor gebruik (Sawada et al. 2002) - in beide Finland en in SuidAfrika. Ons het ook artefakte soos refleksies van SuidAfrikaanse onderwysstudente oor hulle skoolondervindings (WIL) gebruik en 26 Suid-Afrikaanse en twee Finse onderwysers se antwoorde op die Sienings van die Aard van Natuurwetenskappe-vraelys (Views of the Nature van Science [VNOS] wat deur Abd-El-Khalick, Bell en Lederman [1998] ontwikkel is) geanaliseer. Ons sal 'n gedetailleerde analise van die VNOS-vraelys in 'n volgende artikel gee. In hierdie artikel gaan ons net die belangrikste bevinding bespreek. 'n Aantal temas het na vore gekom tydens data-triangulering. Hierdie temas word bespreek en aanbevelings word gemaak. Ons gebruik KHAT as 'n navorsingslens om die spanning of probleme wat in natuurwetenskaponderwys in Suid-Afrika ervaar word, toe te lig en ons wys watter lesse by Finland geleer kan word.

Etiese klaring vir die navorsing is van beide die Universiteit van Johannesburg en die Universiteit van Helsinki verkry, en die foto's wat van leer in Finse skole verskaf word, soos in hierdie artikel vertoon, is geneem met die toestemming van die onderwysers en die leerders. 


\section{'n Bondige oorsig en bespreking van kultuurhistoriese aktiwiteitsteorie as 'n geskikte navorsingslens}

Aktiwiteitsteorie is deur Russiese sielkundiges tydens die 1920 's en 1930's gekonseptualiseer. Dit het die sosiale dimensies van leer en semiotiese instrumentmediëring sterk beklemtoon. Volgens Vygotsky (1978) vind leer plaas tydens sosiale en kulturele wisselwerking tussen kinders en kundige volwassenes. Engeström (1987) het voortgebou op Vygotsky se model en het die derdegenerasie-aktiwiteitsteorie ontwerp. Derdegenerasie-KHAT is by hierdie navorsing as lens betrek omdat dit voortvloei uit sosiaal-konstruktiwisme wat die teoretiese raamwerk is wat dié navorsing begrond. Die skrywers kyk na die voordiensopleiding van onderwysers in die natuurwetenskappe vanuit Warford (2011) se mutasie van die bekende Vygotsky-konstruk (1978) omtrent die sone van proksimale ontwikkeling, naamlik die sone van proksimale onderwyserontwikkeling ten einde te bepaal hoe die professionele ontwikkeling van voordiens-onderwysers maksimaal gesteierbou kan word. KHAT as 'n lens is gekies om na die groter prentjie van natuurwetenskaponderwys in Suid-Afrika en Finland te kyk in 'n poging om moontlike oplossings te identifiseer ten einde sommige probleme van Suid-Afrikaanse natuurwetenskaponderwys op te los.

Kultuurhistoriese aktiwiteitsteorie is op 'n onkonvensionele manier in hierdie artikel gebruik. In stede daarvan om die natuurwetenskaponderwyser of die natuurwetenskapleerder as die subjek te identifiseer, wat die algemene gebruik is wanneer KHAT as navorsingslens gebruik word, het ons 'n subjek gebruik wat nie 'n persoon is nie. Ons kyk sistemies na natuurwetenskaponderwys, en die onderwysstelsel word in hierdie navorsing die subjek. Die objek is sistemiese verbeterings om die tekortkominge in natuurwetenskaponderwys in Suid-Afrika die hoof te bied. In die twee aktiwiteitstelsels is die subjekte dus respektiewelik die Finse en die Suid-Afrikaanse natuurwetenskaponderwysstelsels (raadpleeg Figure 2 en 3).

Rogoff (1990) was die eerste persoon wat gesê het dat daar drie vlakke in sosio-kulturele analise geïdentifiseer kan word, naamlik die persoonlike, die interpersoonlike en die institusionele of gemeenskapsvlakke. KHAT word konvensioneel gebruik as 'n navorsingslens op die persoonlike vlak, waar die subjek 'n individu is, byvoorbeeld 'n onderwyser of 'n leerder, en die oogmerk is die individu se aktiwiteit/ leer/professionele ontwikkeling. Skrywers soos Beatty en Feldman (2009) het KHAT op interpersoonlike vlak gebruik, en het gekyk na die wisselwerking tussen die onderwyser (subjek), die leerders en hulle kennis (objek). In hierdie navorsing het ons KHAT egter op 'n institusionele of gemeenskapsvlak gebruik, met die Suid-Afrikaanse of Finse natuurwetenskaponderwys as subjek. Op dié manier is KHAT gebruik as ' $n$ barometer om bronne van spanning in die bepaalde stelsel van natuurwetenskaponderwys te identifiseer.

Die objek van 'n aktiwiteitstelsel verteenwoordig die probleem waarop die aktiwiteit gerig is (Hardman 2008).
In hierdie artikel is die objek die verbetering van natuurwetenskaponderwys ('n stelsel). Twee stelsels van natuurwetenskaponderwys word vergelyk: aan die een kant die Finse stelsel van natuurwetenskaponderwys, wat Partanen (2011) noem die 'education superpower' wat altyd puik presteer in internasionale toetse soos PISA en TIMSS, en aan die ander kant die stelsel van natuurwetenskaponderwys in Suid-Afrika wat deur swak prestasie in internasionale standaardiseringstoetse gekenmerk word.

Instrumente word beskou as die beskikbare hulpbronne. Die navorsing het op die natuurwetenskapkurrikula in dié twee lande gefokus, met hulpbronne soos handboeke, laboratoria en inligtingkommunikasietegnologie (IKT [rekenaars en sosiale media]), asook die onderrigstrategieë wat in die natuurwetenskapklaskamer ontluik. Taal en die onderrigmedium is ook belangrike faktore. In Finland praat 95\% van die bevolking Fins en die ander 5\% Sweeds. Die meeste van die leerders kry natuurwetenskaponderrig in hulle moedertaal. Dit is in skrille kontras met die situasie in Suid-Afrika, waar die meeste leerders natuurwetenskap in Engels onderrig word, wat dikwels hulle tweede of derde taal is.

Reëls verwys na norme, konvensies en die sosiale wisselwerking wat betrokke is by die aktiwiteitstelsel. Wat hierdie navorsing betref, verwys ons na die beleidsraamwerke, nasionale kurrikula, asook reëls van die gemeenskap. Finse studente wat aansoek doen om onderwysers te word, ondergaan 'n streng keuringsproses: slegs 5\% tot $15 \%$ van studente wat aansoek doen, word gekeur vir onderwysopleidingsprogramme. Wat meer is, onderwysstudente moet 'n meestersgraad hê om in aanmerking te kom vir ' $n$ pos as onderwyser. Verdere 'reëls' wat in gedagte gehou moet word, is die wesenskenmerke van die natuurwetenskap. Daar is bepaalde epistemologiese en ontologiese kenmerke van die natuurwetenskappe (byvoorbeeld dat dit empiries, tentatief en afleibaar is [Cronjé, De Beer en Ankiewicz 2015]), en dit is belangrik dat natuurwetenskappe onderwysers kundig is hieroor.

Die gemeenskap verwys na al die belanghebbendes wat betrokke is: onderwysers, leerders, amptenare van die departement van onderwys, skoolbestuurders en die groter gemeenskap beïnvloed almal natuurwetenskaponderwys in skole.

Werkverdeling (rolverdeling) verwys na verantwoordelikhede, take en magsverhoudinge tussen die verskillende belanghebbendes. Alle belanghebbendes het 'n gesamentlike verantwoordelikheid om natuurwetenskaponderwys van hoë gehalte aan die leerder te verskaf en om 'n bemagtigende leeromgewing te skep. Vir die onderwyser of studenteonderwyser verwys die werks- of rolverdeling na die verskillende fasette van onderwyser wees, byvoorbeeld as onderriggewer, navorser, lewenslange leerder en krities reflektiewe praktisyn. 


\section{Data en bevindinge}

In die onderstaande drie afdelings verskyn ons bevindinge gebaseer op waarnemings tydens klasbesoeke, onderhoude met onderwysers en die onderwysdosente, asook onderwysers se reaksies op die VNOS-vraelys.

\section{Natuurwetenskaponderwys in Finland: Ondersoekende leer wat met behulp van tegnologie bevorder word}

Ons het vier lesse deur drie verskillende onderwysers in Finland waargeneem, en die RTOP-instrument gebruik om ons waarnemings te rig. Die RTOP-instrument (Sawada et al. 2002) verskaf ' $n$ lens om struktuur te gee aan waarnemings van die kontekstuele agtergrond in 'n klaskamer, asook onderrig- en leeraktiwiteite; die klaskamerkultuur (met die fokus op kommunikatiewe interaksies en studentonderwyserverhoudings onderskeidelik); die ontwerp en implementering van die les; en die inhoud (met die fokus op konseptuele en prosedurele kennis).

Tabel 1 bevat ' $n$ opsomming van een van die waarnemings in die klaskamer. (Hierdie inligting word verskaf met die toestemming van die onderwyser.)
Dit is interessant om in Figuur 1 te sien hoe leerders aangemoedig is om hulle selfone of tablette te gebruik om inligting op die internet te kry en ook vir eenvoudige laboratoriumtake soos om tyd te meet.

Ons erken dat daar onderwysers in Suid-Afrika is wat soortgelyke onderwysmetodes gebruik om leerders by oopeinde-ondersoeke in die klaskamer te betrek. 'n Groot persentasie Suid-Afrikaanse onderwysers maak egter nog van direkte onderrig gebruik. Die vier lesse wat ons in Finland bygewoon het, het sonder twyfel getoon dat die onderwysers 'n goeie, genuanseerde begrip van die aard van die natuurwetenskap het. Hierdie onderwysers is die spreekwoordelike 'gids wat langs my staan; nie die alwyse een op die verhoog nie' ('guide on the side, not the sage on the stage'). Die Finse onderwysers wat ons gesien het, het 'n omvattende begrip van selfgerigte leer gehad en die manier waarop koöperatiewe leer gebruik is, is lofwaardig. Foldnes (2015) sê dat koöperatiewe leer plaasvind wanneer studente in 'n groep saamwerk om hulle leerdoelwitte te bereik deur middel van bespreking en portuurterugvoering. Verskeie studies het getoon dat mense wat betrokke is by koöperatiewe leer meer moeite doen om sukses te behaal as mense wat alleen leer (Springer, Stanne \& Donovan 1999). Navorsing toon dat

TABEL 1: RTOP-waarnemings van 'n natuurwetenskap-les in Finland.

\begin{tabular}{|c|c|c|c|c|c|c|}
\hline \multirow{2}{*}{$\begin{array}{l}\text { Aspekte van onderrig-leer } \\
\text { Klaskamerkultuur }\end{array}$} & \multirow{2}{*}{$\begin{array}{l}\text { Beskrywing van onderrig-leermomente } \\
\text { Kommunikatiewe interaksies }\end{array}$} & \multicolumn{5}{|c|}{ Nooit gebeur nie --->--- Baie beskrywend } \\
\hline & & 0 & 1 & 2 & 3 & 4 \\
\hline & $\begin{array}{l}\text { Leerders was betrokke by die kommunikasie van hulle idees aan ander deur ' } n \text { verskeidenheid } \\
\text { middels en media te gebruik. }\end{array}$ & - & - & - & - & $\mathbf{x}$ \\
\hline & Die onderwyser se vrae het uiteenlopende maniere van denke veroorsaak. & - & - & - & - & $\mathrm{x}$ \\
\hline & $\begin{array}{l}\text { Leerders het die meeste van die praatwerk gedoen en 'n beduidende deel daarvan was } \\
\text { leerders wat met mekaar gepraat het. }\end{array}$ & - & - & - & - & $\mathbf{x}$ \\
\hline & $\begin{array}{l}\text { Leerders se vrae en opmerkings het dikwels die fokus en rigting van die } \\
\text { klaskamergesprekke bepaal. }\end{array}$ & - & - & - & $\mathbf{x}$ & - \\
\hline & Daar was 'n klimaat van respek vir wat ander te sê gehad het. & - & - & - & - & $\mathbf{x}$ \\
\hline \multirow{4}{*}{$\begin{array}{l}\text { Leerder-onderwyser- } \\
\text { verhoudings }\end{array}$} & & 0 & 1 & 2 & 3 & 4 \\
\hline & Aktiewe deelname van leerders is aangemoedig en gewaardeer. & - & - & - & - & $\mathbf{x}$ \\
\hline & $\begin{array}{l}\text { Leerders is aangemoedig om met veronderstellings, alternatiewe oplossingstrategieë en } \\
\text { maniere om bewyse te interpreteer vorendag te kom. }\end{array}$ & - & - & - & - & $\mathbf{x}$ \\
\hline & $\begin{array}{l}\text { Die onderwyser het as 'n hulpbron opgetree en het die leerders se ondersoeke ondersteun } \\
\text { en versterk. }\end{array}$ & - & - & - & - & $\mathrm{x}$ \\
\hline \multirow{4}{*}{$\begin{array}{l}\text { Lesontwerp en } \\
\text {-implementering }\end{array}$} & & 0 & 1 & 2 & 3 & 4 \\
\hline & Die les is ontwerp om leerders as lede van 'n leergemeenskap te betrek. & - & - & - & - & $\mathbf{x}$ \\
\hline & Leerders se ondersoek het die formele aanbieding van die les voorafgegaan. & - & - & - & $\mathbf{x}$ & - \\
\hline & $\begin{array}{l}\text { Die les het leerders aangemoedig om na alternatiewe maniere van ondersoek of } \\
\text { probleemoplossing te soek. }\end{array}$ & - & - & - & - & $\mathbf{x}$ \\
\hline \multirow[t]{9}{*}{ Inhoud } & Konseptuele kennis & 0 & 1 & 2 & 3 & 4 \\
\hline & Die les het basiese begrippe van die onderwerp bevat. & - & - & - & - & $\mathrm{x}$ \\
\hline & Die onderwyser het goeie begrip van die vakinhoud van die les gehad. & - & - & - & - & $\mathbf{x}$ \\
\hline & $\begin{array}{l}\text { Elemente van abstraksie (m.a.w. simboliese voorstellings, teoriegenerering) is aangemoedig } \\
\text { toe dit belangrik was om dit te doen. }\end{array}$ & - & - & - & $\mathbf{x}$ & - \\
\hline & Prosedurele kennis & 0 & 1 & 2 & 3 & 4 \\
\hline & $\begin{array}{l}\text { Leerders het 'n verskeidenheid maniere (modelle, tekeninge, grafieke en manipulatiewe } \\
\text { tegnieke) gebruik om verskynsels voor te stel. }\end{array}$ & - & - & - & - & $\mathrm{x}$ \\
\hline & $\begin{array}{l}\text { Leerders het voorspellings, beramings en/of hipoteses opgestel en maniere bedink om dit } \\
\text { alles te toets. }\end{array}$ & - & - & - & - & $\mathrm{x}$ \\
\hline & Leerders het nagedink oor wat hulle geleer het. & - & - & - & $\mathbf{x}$ & - \\
\hline & Intellektuele gestrengheid, opbouende kritiek, en die bevraagtekening van idees is hoog geag. & - & - & - & $\mathbf{x}$ & - \\
\hline
\end{tabular}

Bron: Sawada, D., Piburn, M.D., \& Judson, E., 2002, 'Measuring reform practices in Science and Mathematics classrooms: The Reformed teaching observation protocol', School Science and Mathematics $102(3), 245-253$

Nota: Kontekstuele agtergrond en aktiwiteite: Buite die klaskamer is 'n klerekas met wit laboratoriumjasse aan klerehangers. Soos die leerders die natuurwetenskapklaskamer binnegaan, trek hulle die wit jasse sonder enige opdrag of aansporing van die onderwyser aan. Soos die onderwyser in sy onderhoud verduidelik het, 'betree hulle ' $n$ ander epistemologiese ruimte: dié van die natuurwetenskap'. Leerders haal onmiddellik hulle slimfone of tablette uit. Die onderwyser lei die onderwerp in met ' $n$ kort aanbieding, gebruik ' $n$ baie effektiewe PowerPoint-skyfievertoning en animasie-sagteware. Leerders kry dan die opdrag om laboratoriumondersoeke in klein groepies uit te voer. Geen 'resepte' word gegee nie. In Figuur 1 word foto's van die leerders se ondersoeke verskaf. Leerders gebruik Google om inligting op te spoor, formuleer hipoteses, besluit oor ' $n$ geskikte eksperimentele ontwerp en vra dan vir die onderwyser om klarigheid - inderdaad ' $n$ leerdergesentreerde natuurwetenskap-les, wat klem lê op die wesensaard van die natuurwetenskap. 

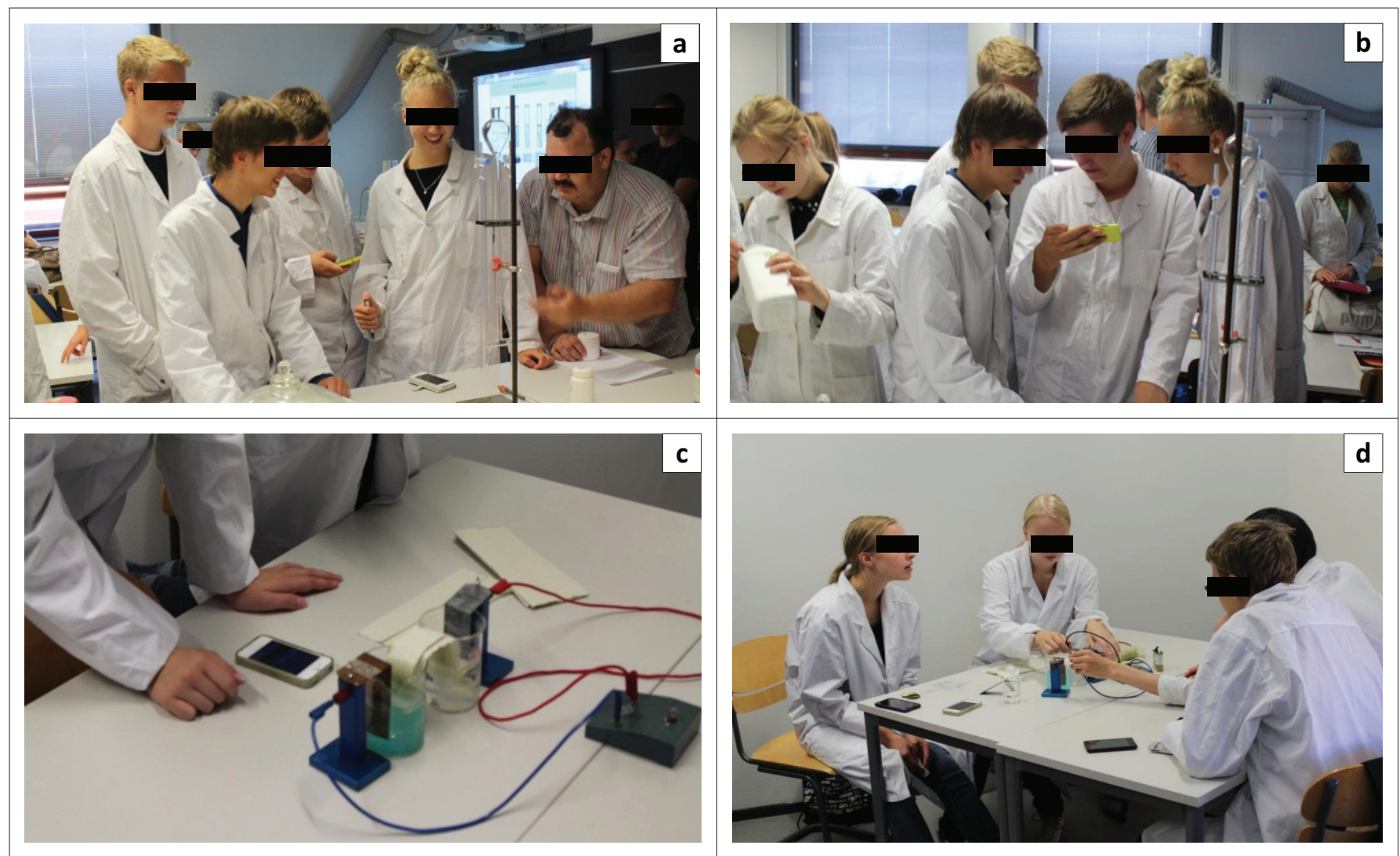

Bron: Foto's geneem (met toestemming van die deelnemers) deur Josef de Beer en Piet Ankiewicz in Helsinki, Finland

FIGUUR 1: Foto's (a-d) geneem tydens 'n natuurwetenskap-les in Finland.

koöperatiewe leer aan sekere kriteria moet voldoen om by te dra tot selfgerigte leer (Johnson \& Johnson 2009). Hierdie kriteria sluit in positiewe interafhanklikheid, individuele toerekenbaarheid en persoonlike verantwoordelikheid, aanmoedigende interaksie; toepaslike gebruik van sosiale vaardighede, en groepverwerking. Hierdie aspekte was tydens ons waarnemings almal duidelik waarneembaar.

\section{Finse onderwysers het genuanseerde onderwysfilosofieë}

Die data van die onderhoude het getoon dat beide onderwysers met wie ons onderhoude gevoer het, genuanseerde onderwysfilosofieë het. Die onderwyser wie se les in die RTOP-instrument in Tabel 1 geanaliseer is, het die onderstaande gesê:

My doelwit is om kennisgenerering sosio-kultureel te ondersteun: om aktiwiteit in die studente se sone van proksimale ontwikkeling (die gebied waar die student 'n mate van ondersteuning nodig het om die volgende vlak van begrip of vaardigheid te bereik), wat sosiaal ondersteun word, te skep. Die studente se voorkennis is die beginpunt, en dan is die leer gebonde aan die aktiwiteit tydens die lesse - eksperimente, simulasies, en waarneming van verskynsels.

Hierdie filosofie van Vygotsky was duidelik sigbaar in die lesse wat ons waargeneem het.

Uit die onderhoud met die onderwysdosent van die Universiteit van Helsinki was dit duidelik dat die ontwikkeling van persoonlike onderwysfilosofieë, gebaseer op literatuur, sowel as refleksie, tydens die opleiding van voornemende onderwysers in Finland beklemtoon word. Beide Schön (1983) se 'refleksie in aksie' en 'refleksie van aksie', asook Thompson en Thompson (2008) se 'refleksie vir aksie' kry aansienlike aandag tydens die opleiding van onderwysers. Onderwysers is kundiges (scholars); dit is duidelik, aangesien 'n meestersgraad nodig is om in Finland skool te hou. 'n Verdere aspek wat opgeval het, is die klem wat Finse onderwysers plaas op klaskameraksie-navorsing. Gravett en De Beer (2016) beskou klaskameraksie-navorsing as in die middel van die kontinuum, tussen refleksie aan die een pool, en formele navorsing aan die ander pool. Finse onderwysers doen aksienavorsing oor hulle onderrigstrategieë, in 'n voortdurende strewe om beter onderwysers te word. Hulle verstaan wat John Slaughter bedoel het, toe hy gesê het:

Research is to teaching what sin is to confession; if you don't participate in the former you have little to say in the latter. [Navorsing doen vir onderrig wat sonde vir belydenis doen; as mens nie betrokke is by eersgenoemde nie, het jy min te sê in laasgenoemde] (Chmielewski \& Stapleton 2009 [outeurs se vrye vertaling]).

Tydens een van die onderhoude met 'n Finse onderwyser is die onderstaande opmerking gemaak:

['n probleem wat ek ondervind, is] ... om studente te motiveer om nie net te leer om probleme op te los nie ... maar hoe ek hulle kan help om meer effektiewe leerstrategieë te ontwikkel ... 
Dit is duidelik uit die onderhoude dat Finse onderwysers streef om selfgerigte leervaardighede by die leerders te ontwikkel. Leerders word aangemoedig om leerdoelwitte te stel, en bronne te identifiseer wat leer sal fasiliteer.

\section{Onderwysers se begrip van die wesenskenmerke van natuurwetenskap}

Abd-El-Khalick et al. (1998) se VNOS-vraelys bestaan uit tien oop vrae, gebaseer op die wesenskenmerke van die natuurwetenskap. Hierdie gevalideerde instrument is gebruik vir beide Suid-Afrikaanse (26) en Finse (2) onderwysers. Met so'n klein steekproef is dit vanselfsprekend nie moontlik om te veralgemeen nie, maar wat duidelik is, is dat die twee Finse onderwysers deeglike, genuanseerde begrip het van die aard van die natuurwetenskap. Een van hulle het gesê:

Een van die dosente wat die grootste invloed op my gehad het, is Derek Hodson. Ek weet nie of jy sy boek gelees het nie (Hodson 2008), maar hy het'n opvatting oor kritiese natuurwetenskaplike geletterdheid; dat 'n student nie net natuurwetenskap leer nie, maar ook hoe om natuurwetenskap in hulle lewens te gebruik.

In teenstelling met die bevindinge van ons navorsing dat Suid-Afrikaanse onderwysers hoofsaaklik die substantiewe aard van die natuurwetenskap (konseptuele kennis) in hulle onderrig beklemtoon, het die Finse onderwysers met wie ons onderhoude gevoer het die sintaktiese aard van die natuurwetenskap (prosedurekennis) beklemtoon. In Finland vind leerders gou uit dat die natuurwetenskap empiries, tentatief, afleibaar, kreatief en gebaseer op teorieë en wette is.

\section{Gebruik kultuurhistoriese aktiwiteitsteorie as 'n lens vir navorsing: lesse uit Finland}

In hierdie afdeling is KHAT, soos vroeër beskryf, op 'n institusionele vlak gebruik om natuurwetenskaponderwys in Finland en Suid-Afrika te vergelyk, om sodoende 'beste praktyke' in Finland te identifiseer wat natuurwetenskaponderwys teen die Suid-Afrikaanse agtergrond kan bevorder.

\section{Finse natuurwetenskaponderwys soos beskou deur'n kultuurhistoriese aktiwiteitsteorie-lens}

Figuur 2 dui aan hoe KHAT as lens gebruik is om Finse natuurwetenskaponderwys te ondersoek en te beskryf.

Dit is belangrik om dit duidelik te stel dat die skrywers besef dat natuurwetenskaponderwys in Suid-Afrika probleme het wat nie in Finland algemeen is nie. Byvoorbeeld, in Suid-Afrika is daar baie kulturele en taaldiversiteit, terwyl in Finland 95\% van die leerders Fins praat en in hulle moedertaal leer. Suid-Afrika kan egter baat vind daarby om te leer uit die wetgewing wat onderwysersopleiding in Finland rig. Finse onderwysers is kundiges wat almal meestersgrade ('n aansienlike gedeelte het Ph.D's) het en betrokke is by aksienavorsing in die klaskamer. Diekeuringsprosesis streng. Dieonderwysdosent

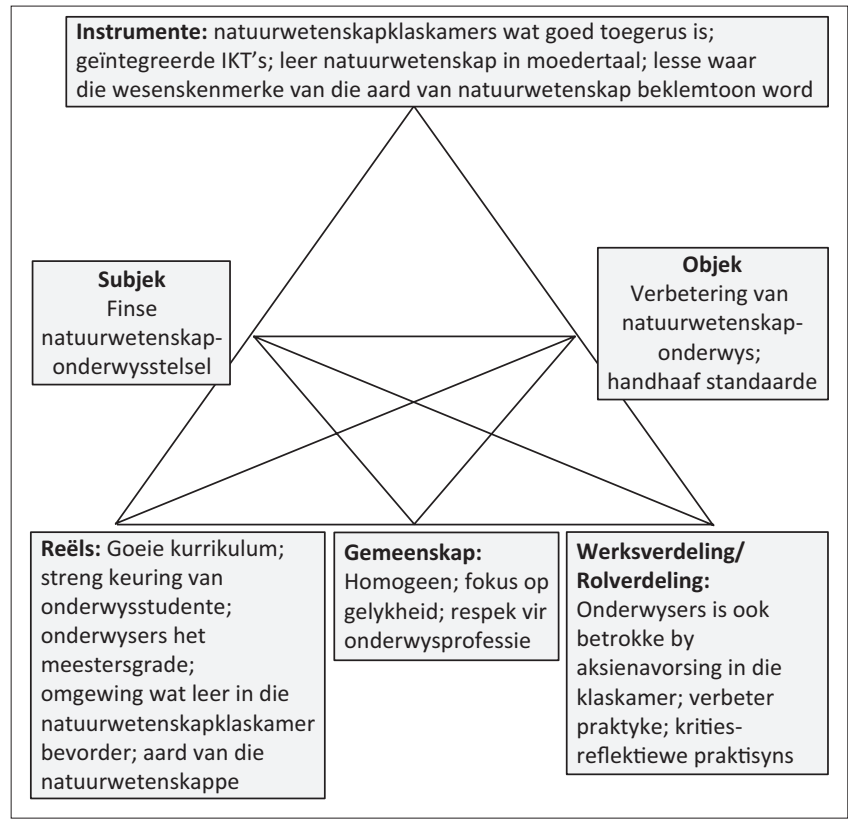

Bron: Gebaseer op Engeström, Y. 2001, 'Expansive learning at work: Toward an activity theoretical reconceptualization', Journal of Education and Work, 14(1), 134-156 FIGUUR 2: Die Finse stelsel van natuurwetenskaponderwys.

aan die Universiteit van Helsinki het genoem dat dit moeiliker is om toelating te kry tot opvoedkunde as wat dit is om toelating te kry tot die mediese fakulteit. Die praktyk van spesiale onderrigskole wat aan die fakulteite van opvoedkunde by universiteite in Finland verbonde is, gee verder aanleiding tot baie effektiewe opleiding vir onderwysers.

Universiteite word dikwels gekritiseer dat hulle studente-onderwysers nie genoegsaam voorberei vir die ingewikkeldheid van die onderwysprofessie nie. Die 'teoriepraktykverdeling' in die opleiding van onderwysers blyk ' $n$ probleem te wees in die opleiding van onderwysers dwarsoor die wêreld (Holland, Evans \& Hawksley 2011; Laverty 2006). Universiteite implementeer verskeie strategieë om die sogenaamde teorie-praktykverdeling die hoof te bied. Die algemeenste strategie is om met skole, waarheen onderwysstudente vir die praktiese komponent van hulle onderwysersopleidingsprogram uitgeplaas word, in vennootskap te tree. Navorsing het getoon dat hierdie praktyk beperkinge het (sien paragraaf 5.2). Twee modelle waarin skole prominente rolle by die opleiding van onderwysers speel, is die professionele ontwikkelingskole in die Verenigde State (Darling-Hammond 2005) en die onderwysersopleidingskole in Finland (Tuovinen 2008). Laasgenoemde model word tans in Suid-Afrika ondersoek. 'n Verslag deur Gravett is in 2015 vrygestel. Die verslag fokus op die geleenthede en probleme om 'n soortgelyke stelsel in Suid-Afrika te vestig (Gravett 2015).

\section{Suid-Afrikaanse natuurwetenskaponderwys deur'n kultuurhistoriese aktiwiteitsteorie-lens}

Onderhoude met onderwysstudente in Suid-Afrika na afloop van hulle tydperk van praktiese onderwys (WIL), beklemtoon wat reeds vroeër in hierdie artikel genoem is. 


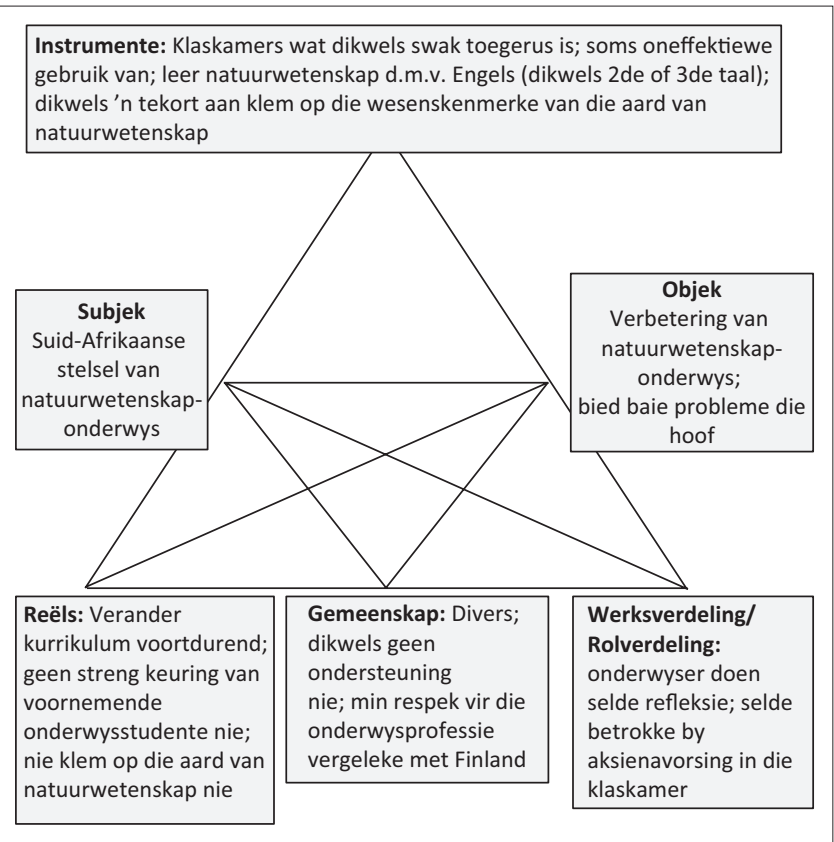

Bron: Gebaseer op Engeström, Y. 2001, 'Expansive learning at work: Toward an activity theoretical reconceptualization', Journal of Education and Work, 14(1), 134-156

FIGUUR 3: Die Suid-Afrikaanse stelsel van natuurwetenskaponderwys.

Onderwysstudente noem dat hulle selde ondersoekende leer in die klaskamers sien, en in die gevalle waar daar wel praktiese werk gedoen word, word 'n resepteboekbenadering dikwels gevolg wat nie die aard van die natuurwetenskap tot eer strek nie. Onderwysstudente het ook genoem dat hulle dikwels nie mentors in die gasheerskole gehad het wat hulle kon help in hulle professionele ontwikkeling nie. 'n Onderwysstudent van die Universiteit van Johannesburg het die onderstaande opmerking gemaak tydens refleksie oor WIL:

Die mentors by die skole waar ons klasgee, gee meestal nie ondersteuning aan die studente nie. Jy vra maar net vir hulle watter werk jy moet doen, en hulle sê vir jou en dis al. Jy moet self uitvind hoe jy die aktiwiteite gaan hanteer, hulle vra nie eens vir jou hoe ver jy is nie. Jy gee maar net klas, en wanneer die tyd aanbreek om die skool te verlaat, vra hulle jou net hoe ver jy gekom het. Jy wys vir hulle wat jy gedoen het, en dis al. Hulle kom nooit na die klas toe om te kom kyk wat jy doen nie. Hulle gee glad nie om vir hulle leerders of onderwysstudente nie. Daar is geen ondersteuning nie.

'n Ander onderwysstudent se kommentaar was:

Wat ek besef het met my ondervinding by 'n skool, is dat onderwysers glad nie praktiese werk doen nie, en as hulle wel praktiese werk doen, is dit resepteboek-aktiwiteite wat dien om te bevestig wat in die handboek staan.

Tientalle lesse van Suid-Afrikaanse onderwysers is ontleed deur van die RTOP-instrument gebruik te maak, en die oorgrote persentasie van hierdie lesse is gekenmerk deur transmissie-modusonderrig, met baie min probleemgesentreerde of selfgerigte leer. Waar praktiese werk gedoen is, was dit hoofsaaklik resepmatige benaderings, met min sprake van probleemoplossing of ontdekkende leer.
In Figuur 3 word KHAT gebruik om aspekte van die SuidAfrikaanse stelsel van natuurwetenskaponderwys te beskryf.

Bronne van spanning kom na vore wanneer die data vanuit 'n KHAT-lens beskou word.

\section{Spanning tussen die vak en die instrumente}

Die Suid-Afrikaanse natuurwetenskapkurrikulum (KABV) skryf leertake soos laboratoriumondersoeke en oop ondersoeke voor. Die vraag is egter of Suid-Afrikaanse onderwysers daartoe in staat is om sulke outentieke leerervarings te verskaf, gegewe die feit dat baie van hulle naïewe sienings het ten opsigte van die aard van die natuurwetenskap. In Finland, aan die ander kant, waar alle natuurwetenskaponderwysers meestersgrade het, het die onderwysers 'n baie goeie begrip van die aard van die natuurwetenskap. Terwyl lesse wat ondersoekende leer in Suid-Afrika bevorder waarskynlik die uitsondering is (in teenstelling met die oorheersende onderrigbenaderings wat van oordrag gebruik maak), is dit in Finland die reël. By beide die opleiding vir voornemende onderwysers en indiensopleiding-intervensies in Suid-Afrika behoort die klem daarop te val om 'n genuanseerde begrip vir die aard van die natuurwetenskap te ontwikkel.

\section{Spanning tussen die bereiking van die objek van die aktiwiteitstelsel en die instrumente wat gebruik word}

Die beskikbare data dui 'n leerkultuur in Finse skole aan. Deur middel van goed gestruktureerde ondersoekende leeraktiwiteite begelei die onderwyser die leerders kundig op 'n ondersoekende reis. Tegnologie soos selfone, tablette en die internet word effektief in die les verweef om leer te bevorder. Suid-Afrikaanse skole, aan die ander kant, word dikwels gekenmerk deur 'n gebrek aan so 'n kultuur van leer, klaskamers met min toerusting en beperkte bemiddeling deur die natuurwetenskaponderwyser. Die skrywers het, tydens navorsing in Suid-Afrikaanse skole, dikwels gesien dat onderwysers leerders beveel om hulle selfone of slimfone af te skakel. Hierdie tegnologie bied moontlikhede vir leer, selfs vir eenvoudige take soos om tyd te meet - 'n aspek wat Finse onderwysers goed gebruik.

\section{Spanning tussen die reëls in die aktiwiteitstelsel, en die subjek/gemeenskap}

Suid-Afrika kan voordeel daaruit trek om kennis te neem van die streng keuringsproses vir onderwysstudente in Finland, asook die praktyk om spesiale skole van onderrig verbonde aan fakulteite van opvoedkunde te vestig, 'n praktyk wat soortgelyk is aan mediese fakulteite wat verbonde is aan akademiese hospitale. Die Universiteit van Helsinki het byvoorbeeld hegte bande met die Viiki-skool in Helsinki, en daar is noue samewerking tussen onderwysdosente en onderwysers by die skool. Verder behoort die aard van die natuurwetenskappe (byvoorbeeld dat dit empiries, tentatief en afleibaar is) veel meer klem in onderwyseropleiding in Suid-Afrika te geniet. 


\section{Spanning verbonde aan werksverdeling (rolverdeling)}

'n Kenmerk van Finse opleiding is dat onderwysers ook kundiges is wat betrokke is by aksienavorsing in die klaskamer. Dit vorm 'n skerp teenstelling met Suid-Afrika waar net 'n klein persentasie onderwysers by aksienavorsing in die klaskamer betrokke is. Ons moet vakkundigheid (scholarship) van onderrig in Suid-Afrika vestig, en onderwysers oplei om die rol van navorsing in onderrig te waardeer.

\section{Aanbevelings en gevolgtrekking}

Die voorsiening van meer effektiewe mentorskap tydens die opleiding van voornemende onderwysers, veral tydens WIL, vereis aandag in Suid-Afrika. Kritiese refleksie oor onderwys moet beklemtoon word by beide die opleiding van voornemende onderwysers en diensdoende onderwysers, en onderwysers se metakognitiewe vaardighede moet ontwikkel word. Die vakkundige ontwikkeling (scholarship) van onderwysers, asook die besef van die vele rolle van 'n onderwyser as onderriggewer, krities reflektiewe praktisyn, navorser en lewenslange leerder, moet beklemtoon word, en onderwysers moet opgelei word om aksienavorsing in die klaskamer te doen. Ontwikkeling van die pedagogiese inhoudskennis (PIK) van onderwysers moet ook die wesenskenmerke van die aard van die natuurwetenskap bevorder. Een van die kenmerke van Finse opleiding is dat onderwysers 'n baie goeie begrip het van die wesenskenmerke van die natuurwetenskap, wat lei tot die skep van opwindende, ondersoekende oopeinde-leeraktiwiteite. Finse onderwysers het ook 'n goeie begrip van die ontwikkeling van selfgerigte leervaardighede by leerders.

Tydens refleksie oor 'n navorsingstudie wat gedoen is oor die vestiging van onderrigskole in Suid-Afrika, het Gravett (2015) beweer dat dit makliker gesê as gedaan is om die wêreld van die universiteitsklaskamer (die spreekwoordelike ivoortoring) te integreer met die wêreld van die skoolklaskamer (die spreekwoordelike 'steenkoolveld' waar krisisse hulle uitspeel) as plekke om te leer. Om die begrip van onderwyseropleiers (akademiese personeel in Fakulteite van Opvoedkunde) met betrekking tot die aard en omvang van leer deur onderwysstudente te integreer in onderskeidelik die lesinglokaal op universiteit, en in die skoolklaskamer, asook om hulle onderskeie rolle te vervul om die wêreld van akademiese kursusse met die wêreld van skoolhou te laat 'praat', is as uitdagings in hierdie verslag uitgewys. Die idee van spesiale skole van onderrig is duidelik 'n aspek wat verder nagevors behoort te word.

Ons sluit af met 'n bondige bespreking van navorsing wat deur De Beer en Gravett (n.d.) gedoen is. Hierdie skrywers het 'n innoverende intervensie geïmplementeer waartydens voorgraadse onderwysstudente aan die Universiteit van Johannesburg die geleentheid gegee is om Lewenswetenskappe te onderrig by 'n hoëprestasie-skool wat weliswaar nie Lewenswetenskappe as vak aanbied nie (en dus nie Lewenswetenskaponderwysers het nie).
Die skrywers voer aan dat hierdie intervensie die drie basiese probleme betrek het aangaande die leerproses van wat onderwyser wees, beteken, naamlik (1) die probleem van die vakleerlingskap van waarneming (Lortie 1975 se konstruk van die 'apprenticeship of observation'); (2) die probleem van toepassing; en (3) die probleem van 'n begrip van die kompleksiteit van die onderwysprofessie, en wat onderwyser wees beteken. Die Japannese lesstudiebenadering, waar onderwysstudente lesse voorberei en in groepe van vier elk aanbied, is verder uitgebrei in die projek met behulp van die tegniek van prolepsis, wat die strukturering van 'n leergeleentheid op so 'n manier behels dat dit aanneem dat die onderwysstudente meer weet as wat hulle eintlik weet (De Beer \& Gravett n.d.).

Deur so ' $n$ proleptiese benadering in onderwysersopleiding te gebruik, kan die onderwysdosent die optimale afstand tussen die onderwysstudent se werklike en moontlike ontwikkeling ondersoek (Warford 2011). Hierdie intervensie verskil van die gewone skoolondervinding in dié opsig dat voornemende onderwysstudente 'praktiserende onderwysers' word wat die volle verantwoordelikheid vir leeraktiwiteite tydens 'n hele akademiese jaar aanvaar, in teenstelling met wat dikwels tydens WIL gebeur. Hierdie outentieke uitlewing in die onderwys, gekoppel aan effektiewe mentorskap (deur die onderwysdosente) hou moontlikhede in vir die effektiewe opleiding van Lewenswetenskaponderwysers.

Ten slotte kan gesê word dat, ondanks die verskille tussen die Finse en Suid-Afrikaanse stelsels vir natuurwetenskaponderwys en die ingewikkeldheid van natuurwetenskaponderwys in Suid-Afrikaanse multikulturele klaskamers met beperkte hulpbronne, daar baie beste praktyke in Finland is wat effektief in Suid-Afrika toegepas kan word.

\section{Erkenning}

Die outeure bedank die Universiteit van Johannesburg vir befondsing, asook die Nasionale Navorsingstigting (NNS).

\section{Mededingende belange}

Die outeure verklaar dat hulle geen finansiële of persoonlike verbintenis met enige party wat hulle nadelig of voordelig kon beïnvloed het in die skryf van hierdie artikel nie.

\section{Outeursbydrae}

J.d.B. en P.A. het gesamentlik die artikel gekonseptualiseer. Beide outeure was betrokke by die veldwerk in beide SuidAfrika en Finland, en het gesamentlik die artikel geskryf, met eweredige werksverpreiding.

\section{Literatuurverwysings}

Abd-El-Khalick, F., Bell, R.L. \& Lederman, N.G., 1998, 'The nature of science and instructional practice: Making the unnatural natural', Science Education 82, 417-436.

Beatty, I.D. \& Feldman, A., 2009, 'Illuminating teacher change and professional development with CHAT', Proceedings of the NARST 2009 Annual Meeting, Garden Grove, CA, April 17 - 212009. 
Chmielewski, J.G. \& Stapleton, M.G., 2009, 'The undergraduate research experience: It's really not for everyone', BIOS 80(2), 53-58. https://doi.org/10.1893/ It's really not
011.080 .0201

Cronjé, A., De Beer, J. \& Ankiewicz, P., 2015, 'The development and use of an instrument to investigate science teachers' views on indigenous knowledge', African Journal of Research in Mathematics, Science and Technology Education 19(2), 319-332. https://doi.org/10.1080/10288457.2015.1108567

Darling-Hammond, L. (ed.), 2005, Professional development schools: Schools for developing a profession, Teachers College Columbia University, New York.

De Beer, J. \& Gravett, S., n.d., 'Bungee-jumping across the zone of proximal teacher development: A case study of a different approach to practice teaching', unpublished manuscript.

De Beer, J.J.J. \& Ramnarain, U., 2012, 'The implementation of the FET Physical- and Life Sciences curricula: Opportunities and challenges', unpublished report prepared for the Gauteng Department of Education, UJ Library, University of Johannesburg.

Engeström, Y., 1987, Learning by expanding: An activity-theoretical approach to developmental research, Orienta-Konsultitl, Helsinki.

Engeström, Y., 1999, 'Activity theory and individual and social transformation', Perspectives on Activity Theory 19-38.

Engeström, Y. 2001, 'Expansive learning at work: Toward an activity theoretical reconceptualization', Journal of Education and Work, 14(1), 134-156.

Foldnes, N., 2015, 'The flipped classroom and cooperative learning: Evidence from a randomised experiment', pp. $39-49$, viewed 20 January 2017 from http://brage. bibsys.no/bi

Gravett, S., 2015, Establishing teaching schools in South Africa, unpublished research conducted for the Department of Higher Education, University of Johannesburg.

Gravett, S. \& De Beer, J., 2016, 'The teacher as a researcher', in S. Gravett, J.J. de Beer \& E. du Plessis (eds.), Becoming a teacher, pp 344-355. 2nd ed., Pearson, Cape Town.

Hailman, J.P., 1975, 'The scientific method: Modus operandi or supreme court?', The American Biology Teacher 37(5), 309-310. https://doi.org/10.2307/4445245

Hardman, J., 2008, 'Research in pedagogy: An activity theory approach', Journal of Education 45(1), 65-95.

Hodson, D., 2008, Towards scientific literacy: A teacher's guide to the history, philosophy and sociology of science, Sense Publishers, Rotterdam, The Netherlands.

Holland, M., Evans, A. \& Hawksley, F., 2011, 'International perspectives on the theorypractice divide in secondary initial teacher education', annual Meeting of the Association of Teacher Educators in Europe, 24-28 August, Riga, Latvia.
Johnson, D.W. \& Johnson, R.T., 2009, 'An educational psychology success story: Social interdependence theory and cooperative learning', Educational Researcher 38(5), 365-379. https://doi.org/10.3102/0013189X09339057

Laverty, M., 2006, 'Philosophy of education: Overcoming the theory-practice divide', Paideusis 15(1), 31-44.

Lortie, D., 1975, Schoolteacher, University of Chicago Press, Chicago, IL.

Partanen, A., 2011 The Atlantic, 29 December 2011, viewed 20 January 2017 from $\mathrm{http}: / /$ www.theatlantic.com/national/archive/2011/12/what-americans-keepignoring-about-finlands-school-success/250564/

Ramnarain, U.D., 2007, 'A study of the implementation of scientific investigations at grade 9 with particular reference to the relationship between learner autonomy and teacher support', Unpublished doctoral dissertation, University of KwaZuluNatal.

Rogan, J. \& Aldous, C., 2005), 'Relationships between the constructs of a theory of curriculum implementation', Journal of Research in Science Teaching 42(3), 313-336.

Rogoff, B., 1990, Apprenticeship in thinking: Cognitive development in social context, Oxford University Press, New York.

Sahlberg, P., 2010, The secret to Finland's success: Educating teachers, Stanford Centre for Opportunity Policy in Education, Stanford University, Stanford, CA, viewed n.d., from https://edpolicy.stanford.edu/publications/pubs/290

Sawada, D., Piburn, M.D., \& Judson, E., 2002, 'Measuring reform practices in Science and Mathematics classrooms: The Reformed teaching observation protocol', School Science and Mathematics 102 (3), 245-253.

Schön, D., 1983, The reflective practitioner, Basic Books, New York.

Springer, L., Stanne, M.E. \& Donovan, S.S., 1999, 'Effects of small-group learning on undergraduates in science, mathematics, engineering and technology: A meta-analysis', Review of Educational Research 69(1), 21-51. https://doi. A meta-analysis', Review of Education

Thompson, S. \& Thompson, N., 2008, The critically reflective practitioner, Palgrave Macmillan Hampshire.

Tuovinen, J.E., 2008, 'Teacher professionalism - Viewpoints on best practice; the case of Finland', Paper delivered at the AARE Conference, Brisbane, Australia, 30 November - 04 December 2008.

Vygotsky, L.S., 1978, Mind in society, Harvard University Press, London.

Warford, M.K., 2011, 'The zone of proximal teacher development', Teaching and Teacher Education 27(2), 252-258. https://doi.org/10.1016/j.tate.2010. 08.008 